\begin{tabular}{cc}
\hline International Journal of Engineering \& Technology, $7(4.33)(2018) 191-194$ \\
SPC & Website: www.sciencepubco.com/index.php/IJET \\
Research paper & International Journal of Engineering \& Technology \\
\hline
\end{tabular}

\title{
Literature Review: Authentic Assessment in Vocational High Schools
}

\author{
Nafisa Firmania ${ }^{1 *}$, Putu Sudira ${ }^{2}$, Asnul Dahar Minghat ${ }^{3}$ \\ ${ }^{1}$ Vocational and Technology Education, Postgraduate Program, Yogyakarta State University, Indonesia \\ ${ }^{2}$ Instructional Technology, Postgraduate Program, Yogyakarta State University, Indonesia \\ ${ }^{3}$ Razak Faculty of Technology and Informatics, University of Technology Malaysia, Malaysia \\ *Corresponding author E-mail: nafisafirmania27@gmail.com
}

\begin{abstract}
Assessment is an activity that must be done in each lesson. Educational assessment is the process of gathering and processing information to determine the achievement of student learning outcomes. A good assessment must be carried out both in the learning process and in the final learning outcomes. The teaching and learning process in Vocational High Schools includes an explanation of science or study subjects and practice. With the complexity of learning in the Vocational High School, the assessment that is applied must be appropriate and can include the assessment of students as a whole. The assessment applied at the Vocational High School at this time is authentic assessment, where the assessment assesses three aspects of each student. The three aspects namely knowledge assessment, skills assessment and attitude assessment. Authentic assessment measures the overall student learning outcomes because this assessment assesses the progress of student learning not just the end result of student learning. Vocational high school students are prepared to work, therefore not only knowledge and skills must be invested because attitude is more important than both aspects. In other words, vocational high school students must be able to balance their knowledge and skills and be accompanied by a good attitude in each process.
\end{abstract}

Keywords: assessment; authentic assessment; vocational high school; learning; knowledge; skill; attitude.

\section{Introduction}

The learning process especially in Vocational High Schools is influenced by several factors. These factors include curriculum, learning methods applied, teaching subjects used and practicum facilities provided. In this modern age, there are many who think that the assessments made in Vocational Schools are based on students' ability in learning activities in the classroom, in practical work and in work practices outside of school [1]. The assessment benchmarks that have now become the guidelines for almost all Vocational Schools are authentic assessments [2]. This authentic assessment can assess students in three domains of assessment, namely: attitude assessment, knowledge assessment and skills assessment [3].

Knowledge is the basis on which a Vocational High School student understands the subjects before they practice. In increasing knowledge of students, a teacher can provide insight or explanation to students about the subjects that must be mastered by students. If knowledge has been mastered by students, the teacher gives practice to students where the practice aims to train student skills. Between the knowledge and skills that must be possessed by Vocational High School students must be balanced. When they master the subjects, they must also be able to practice it. Both aspects must always be balanced. Because knowledge without good skills will be in vain and vice versa. If knowledge and skills have been balanced, the third aspect of this attitude is the main determinant. A good attitude will affect someone in doing a job. If knowledge and skills are good enough, but the attitude of someone is not good, it can be ascertained in the world of work that person will not have a good career. With a few descriptions above, every school, especially Vocational High Schools, needs to conduct an assessment. The form of assessment is adjusted to the applicable curriculum.

Knowledge assessment is carried out by teachers who teach in each subject. Skill assessment is carried out by the teacher who assesses the practices that have been carried out by students. While attitude assessment is usually carried out by Counseling Guidance teachers, religious teachers and Citizenship Education teachers. Attitude assessment should not only be carried out by Counseling Guidance teachers, religious teachers and Civic Education teachers only, because the attitudes of students when they are in the classroom receive the subject matter and attitudes of students when the practice should also be given an assessment by the teacher.

Assessment should also be used to determine strengths and weaknesses in the learning process, as well as to make diagnoses and improve learning processes. A meaningful learning process requires a good, planned and continuous assessment system. Authentic assessment covering the three domains of assessment, is an appropriate assessment applied in this modern era. The assessment can also re-instill student attitudes that tend to be less neglected at this time [4].

Authentic assessment measures the overall student learning outcomes because this assessment assesses the progress of student learning not just the end result of student learning [5]. With an authentic assessment the teacher can perform various assessment techniques to be able to measure aspects of attitudes, skills and knowledge that can be evaluated, namely the assessment of learn- 
ing outcomes [6]. Assessment of student competencies consisting of attitude assessment, knowledge assessment, and skills assessment is still considered difficult for teachers to implement. However, if the assessment is applied slowly then there will be no more problems in the application of authentic assessment.

\section{Literature Review}

\subsection{Vocational High School}

Vocational High School is one of the secondary education levels with the specialty of preparing graduates to be ready to work. Vocational High Schools or also referred to as vocational education is education that directs to develop skills, in accordance with certain fields of work that hope to create jobs [7]. In accordance with the learning objectives of vocational education, it emphasizes skills learning in accordance with the demands of the industrial world or the world work. In vocational education, skills or expertise are better known as competence or performance.

The specific objectives of vocational secondary education are as follows: (a) preparing students to become productive human beings, able to work independently, fill job openings as middle-level workers in accordance with the competencies in the chosen expertise program; (b) prepare students to be able to choose a career, be tenacious and persistent in competence, adapt to the work environment and develop professional attitudes in the areas of expertise they are interested in; (c) equip students with science, technology and art to be able to develop themselves later on both independently and through higher education; and (d) equip students with competencies in accordance with the chosen expertise program [8].

\subsection{Learning}

Learning is an effort made by a teacher or educator to teach students who are done by a teacher or educator to teach students who are learning [9]. Learning is an accumulation of teaching concepts and learning concepts [10]. The emphasis lies in the combination of the two namely on the growth of students' activities. Learning activities are no longer merely teaching activities (teaching) that ignore learning activities, namely simply preparing teaching and carrying out teaching procedures in face-to-face learning. However, learning activities are more complex and carried out with varied learning patterns [11]. Learning is essentially related to how to build good interaction between the two components, namely the teacher and students. A good interaction can be described in a condition where the teacher can make students learn easily and are motivated by their own willingness to learn what is in the curriculum as their needs [12]. To be able to develop an effective learning method, each teacher is required to have an adequate knowledge regarding the concept and ways of implementing the learning method in the teaching and learning process [13]. Apart from that, the learning in it contains complex phenomena in which there are various abilities, willingness and potential of students. Where teachers and students are required to always be active and follow the development of increasingly modern learning from the era to the era.

\subsection{Authentic Assessment}

Assessment is a systematic and systemic effort that is carried out through data collection or information that is valid and reliable, and then the data or information is processed as an effort to make consideration for policy making of an educational program [14]. Assessment (assessment) is the process of gathering and processing information to measure the achievement of learning outcomes of students [15]. In general, teachers conduct assessments in class related to teaching and learning activities in an effort to collect data, facts, and learning documents for students with the aim of improving learning programs [16]. Appropriate assessment will be able to reflect or reflect the learning process or event experienced by students. In Vocational Schools, the assessment used at this time is authentic assessment.

Authentic assessment is a type of assessment that directs students to demonstrate the skills and competencies needed to overcome problems and situations encountered in the real world [16]. Authentic assessment is a comprehensive assessment to assess starting from input, process, and learning output, which includes the realm of attitudes, knowledge, and skills [17]. Authentic assessment assesses the readiness of students, as well as the whole process and learning outcomes. The integrated assessment of the three components (input-process-output) will illustrate the capacity, style, and learning outcomes of students, even capable of producing instructional effects and the companion effects of learning.

The competency is a combination of skills based on knowledge and carried out with the appropriate attitude. Someone has not been able to say competently if his attitude in demonstrating skills is not according to what they should be. Mueller stated that authentic assessment is a direct assessment because students immediately show proof of competency mastery when evaluating.

Table 1: Differences in traditional assessment and authentic assessment [14]

\begin{tabular}{|c|c|}
\hline Traditional Assessment & Authentic Assessment \\
\hline Selecting response & Shows the task / performance \\
\hline Academic knowledge & Real world assignments \\
\hline $\begin{array}{c}\text { Measuring the application of } \\
\text { knowledge }\end{array}$ & $\begin{array}{c}\text { Enriching the development of } \\
\text { meaningful competencies }\end{array}$ \\
\hline Remember /understand & Construction / application \\
\hline Structuring by teachers & Structuring by students \\
\hline Indirect evidence & Direct evidence \\
\hline $\begin{array}{c}\text { Measuring knowledge about } \\
\text { "WHAT" }\end{array}$ & Measuring knowledge about \\
"HOW" \\
\hline $\begin{array}{c}\text { Supports convergent ways of } \\
\text { thinking to present one right } \\
\text { answer }\end{array}$ & $\begin{array}{c}\text { Supports divergent thinking to } \\
\text { present several answer choices }\end{array}$ \\
\hline
\end{tabular}

A student can be said to be competent if they can demonstrate their ability to apply knowledge acquired in all situations and conditions that occur. Each type of assessment depends on its purpose. Authentic assessment, according to Wiggins '98 is designed to: (1) make students successful learners with acquired knowledge (2) provide students with a full range of skills (e.g., research, writing, revising, oral skills, debating, and other critical skills) (3) demonstrate whether the student can generate full and valid relations answers to the task or challenge at hand (4) provide reliability by offering suitable and standardized criteria for tasks and challenges (5) give students the chance to rehearse 'Critical thinking in achieving their future adult and professional lives [18].

\subsection{Implementation of Authentic Assessment in Voca- tional High School}

The application of authentic assessments in Vocational High Schools can be carried out during learning (assessment of the process) and after learning is completed (product assessment). When the assessment is given during the learning process, the subject teacher or practicum teacher must pay attention to all aspects. If you look deeper than the teacher must pay attention to how students receive the knowledge given by the teacher and whether they can practice it. However, their attitude when receiving knowledge in the form of learning and practice after receiving the knowledge also requires detailed assessment. In authentic assessment, all teachers, especially teachers in Vocational Schools, are intended to be creative and have an assessment that is in accordance with the established guidelines [20]. The implementation of authentic assessments in Vocational High Schools aims to shape the character of students which when they come down in the world work they will be person who is daytime and tough to face all the situations and conditions they will receive. Assessments that not only focus on knowledge and skills alone, will actually help students to become intelligent and having a good character 
[21]. In authentic assessment pay attention to the balance between competency assessment of attitudes, knowledge, and skills that are adjusted to the development of the characteristics of students in accordance with the level.

\section{Methodology}

Research is a study of literature studies by examining several journals that are relevant to authentic assessment. The result of literature review will be used to analyze how to apply authentic assessment in vocational high school.

\section{Results and Discussion}

\subsection{Balancing between Competency Assessment of Knowledge, Skills and Attitudes That Are Adapted to the Development of the Characteristics of Students}

Authentic assessment consists of three assessment points, namely: knowledge assessment, skills assessment and attitude assessment Then how can these three aspects run in balance? Assessment of the achievement of students' knowledge competencies is an intellectual potential assessment consisting of levels of knowing, understanding, applying, analyzing, evaluating, and creating. Assessment of students' knowledge can be done through written tests, oral tests, and assignments. Knowledge competency assessment techniques are carried out with written tests, oral tests, and assignments. Each of these techniques is carried out through certain relevant instruments. Knowledge assessment is carried out in each learning process, both when the teacher gives an explanation of the learning subjects as well as an assessment of the tasks given by the teacher to students. In each process the teacher must pay attention to the process of delivering the subjects and the tasks that will be given to students. At the stage of assessing aspects of knowledge assessment, the teacher can insert an attitude assessment in it. The attitude assessment intended here is the student's acceptance about the subjects. Whether the student can receive the subjects with a good attitude or not, then if given the assignment can also be assessed whether the student is doing the task honestly or not. So, in the assessment of knowledge, not only does the teacher provide knowledge assessment but also needs to be accompanied by an attitude assessment.

Assessment of achievement of skills competencies is an assessment carried out on students to assess the extent of achievement in the skill dimension. This assessment is usually carried out after the process of delivering subjects by the teacher to students. As with the assessment of knowledge competencies, in assessing these skills competencies the teacher can also assess attitudes when students work on or practice practical tasks given by the teacher. The assessment of attitudes in these skills competencies also teaches students how to work when working on a job in the world of work by means of a letter or by being good. The correlation between the three aspects of authentic assessment will affect students later in the world of work.

Any work and anywhere, knowledge and skills are very influential. However, if someone has good knowledge and competent skills without being based on a good attitude will be in vain. However, people who are met later in the world of work both at work in the company and entrepreneurs will always consider and assess our attitude.

\subsection{The Role of Teacher in Maximizing the Application of Authentic Assessments in Vocational Schools}

The role of teacher in maximizing the application of authentic assessments in Vocational Schools. The teacher will convey the learning process that has been adapted to the applicable curriculum. The current curriculum aims to prepare people to have the ability to live as individuals and citizens who are faithful, produc- tive, creative, innovative and affective and able to contribute to the life of the world, nation, state and world civilization. With the curriculum being continuously improved from time to time, it is hoped that there will be a balance between developing attitudes, spiritual and social, curiosity, creativity, cooperation with intellectual and psychomotor abilities.

In addition to the curriculum the next factor that influences the capabilities of vocational high school graduates is learning. Learning is an important process in the world of education. Learning methods and models implemented in Vocational Schools are adjusted to the area of expertise and characteristics of students. A learning process can produce maximum and appropriate work competencies if the methods and models used are appropriate. Learning is a varied process. Where an educator can do several models and methods of learning in a teaching and learning process However, the learning carried out must be balanced between students' knowledge, skills and attitudes.

Knowledge and skills of Vocational High School students must be adjusted to work competencies. Work competency is a reference for students where they can find out what work ability formulations include several things, namely knowledge, skills or expertise and relevant work attitudes. Relevant work competencies will make it easier for SMK graduates to find work in the world of work. At this time many Vocational Schools have had cooperation with industry and agencies in order to absorb alumni in the world of work.

Of the various factors described above, there are three aspects that always affect each of these factors. These three aspects, namely knowledge, skills, and attitudes. Vocational High School has no exception to assess the students for these three aspects based on the current curriculum. Knowledge is the basis on which a student understands the subjects before they practice. In increasing knowledge of students, a teacher can provide insight or explanation to students about the subjects that must be mastered by students. If knowledge has been mastered by students, the teacher gives practice to students where the practice aims to train student skills. Between the knowledge and skills that students must possess must be balanced. When they master the subjects, they must also be able to practice it. Both aspects must always be balanced. Because knowledge without good skills will be useless and vice versa. If knowledge and skills have been balanced, then the third aspect of this attitude is the main determinant. Good attitude will affect someone in doing a job. If knowledge and skills are good enough, but the attitude of someone is not good, it can be ascertained in the world of work that person will not have a good career With a number of reflections above, every school, especially Vocational Schools, needs to hold an assessment. The form of assessment is adjusted to the applicable curriculum.

Assessment of the current curriculum includes assessment of knowledge, assessment of skills and attitude assessment. Knowledge assessment is carried out by teachers who teach in each subject. Skill assessment is carried out by the teacher who assesses the practices that have been carried out by students. While attitude assessment is usually carried out by Counseling Guidance teachers, religious teachers and Citizenship Education teachers. Attitude assessment should not only be carried out by Counseling Guidance teachers, religious teachers and Citizenship Education teachers only, because students' attitudes when they are in the classroom receive the subject matter and student attitudes when the practice should also be assessed by the teacher. Assessment should also be used to determine strengths and weaknesses in the learning process, as well as to make diagnoses and improve learning processes. A meaningful learning process requires a good, planned and continuous assessment system. So, the role of the teacher is very important in instilling positive things to students before the teacher gives an assessment. Teachers are required to be able to understand the characteristics of students If the teacher can guide his students well, it is not impossible if the application of authentic assessments especially in Vocational High Schools gets maximum results. 


\section{Conclusion}

Assessment is an important process in all learning activities. Assessments conducted in Vocational High Schools must be appropriate. Authentic assessment that is applied at this time in Vocational High Schools includes three aspects of assessment of each student namely attitude assessment, knowledge assessment and skills assessment. All aspects of authentic assessment must be balanced. Teachers as facilitators in the assessment must be wise and can lead students to maximize the three aspects of the assessment. This authentic assessment, also seeks to familiarize and teach students how they must use knowledge and behave in situations and conditions where they will work later.

\section{References}

[1] Haryono, A. (2009). Authentic assessment dan pembelajaran inovatif dalam pengembangan kemampuan siswa. Jurnal Pendidikan Ekonomi, 2(1)., 1-12.

[2] Arif, R. (2009). Memahami pendidikan dan ilmu pendidikan. Laksbang Mediatama Yogyakarta.

[3] Emery, D. E. (2001). Authentic assessment in high school science: A classroom perspective. In D. P. Shepardson (Ed.), Assessment in Science. Dordrecht: Kluwer Academic Publishers, 227-247.

[4] Gipps, C. V. (1994). Beyond testing: Towards a theory of education assessment. The Falmer Press.

[5] Sudira, P. (2018). Metodologi pembelajaran vokasional abad XXI. UNY Press.

[6] Orpwood, G. (2001). The role of assessment in science curriculum reform. Assessment in Education: Principles, Policy and Practice, 8(2), 135-152.

[7] Sudira, P. (2018). TVET abad XXI. UNY Press.

[8] Moodie, G. (2002). Identifying vocational education and training. Journal of Vocational Education and Training, 54(2), 249-266.

[9] Puckett, M. B., \& Black, J. K. (2000). Authentic assessment of the young child: Celebrating developing and learning. PrenticeHall.

[10] Toto, R. (2011). Kurikulum dan pembelajaran. Rajagrafindo Persada.

[11] Venkatesh, V., \& Davis, F. D. (2000). A theoretical extension of the technology acceptance model: Four longitudinal field studies. Management Science, 46(2), 186-204.

[12] Law 3191/2003. The National System of Connection of Vocational Education and Training with Employment (N.S.C.V.E.T.). Issue A (258), 4497-4508.

[13] Vretakou, V., \& Rouseas, P. (2002). Vocational education and training in Greece. Cedefop reference series 50. Bureau of Formal Editions of the European Communities.

[14] Sani, A. (2016). Penilaian autentik. Bumi Aksara.

[15] Gulikers, J. T. M., Bastiaens, T. J., \& Kirschner, P. A. (2004). A five-dimensional framework for authentic assessment. Educational Technology, Research and Development, 52(3), 67-86.

[16] Syawal, G. (2013). Modul Pelatihan Implementasi Kurikulum 2013 SMA/SMK. Badan Pengembangan Sumber Daya Manusia Pendidikan dan Kebudayaan dan Penjaminan Mutu Pendidikan. Kementerian Pendidikan dan Kebudayaan.

[17] Newmann, F. M., \& Archbald, D. A. (1992). The nature of authentic academic achievement. In H. Berlak, F. M. Newmann, E. Adams, T. Burgess, J. Raven, \& T. A. Romberg (Eds.), Toward a New Science of Educational Testing and Assessment. State University of New York Press, pp. 71-83.

[18] Kusnandar. (2013). Penilaian authentic (Penilaian hasil belaja peserta didik berdasarkan kurikulum 2013). Raja Grafindo Persada.

[19] Wiggins, G. (1998). Educative assessment: Designing assessment to inform and improve student performance. Jossey Bass.

[20] Stufflebeam, D. L., \& Antohony, J. S. (1986). Systematic evaluation, a self-instructional guide to theory and practice. KluwerNijhoff Publishing.

[21] Wahyu, F. (2015). Kurikulum dari masa ke masa 2009. Journal, 10 Tahun 2015. 